\title{
MRCPsych Examinations Autumn 1987
}

Entries should be despatched to arrive not earlier than six weeks before and not later than the closing dates shown below. Candidates who wish to claim credit for psychiatric experience gained outside the UK or Eire, should submit their applications at least three weeks before the cloaing date. Application forms are available on written request to the Examinations Officer. Late or incomplete entries are not sccepted.

\begin{tabular}{lcccccc}
\hline & $\begin{array}{c}\text { Closing date } \\
\text { for receipt } \\
\text { of applications }\end{array}$ & $\begin{array}{l}\text { Written } \\
\text { papers }\end{array}$ & $\begin{array}{c}\text { Clinical } \\
\text { examination } \\
\text { (week beginning) }\end{array}$ & $\begin{array}{c}\text { Oral } \\
\text { examination }\end{array}$ & $\begin{array}{c}\text { Results } \\
\text { mailed } \\
\text { on }\end{array}$ & $\begin{array}{c}\text { Results } \\
\text { displayed on } \\
\text { College board }\end{array}$ \\
\hline $\begin{array}{l}\text { MRCPsych } \\
\begin{array}{l}\text { Part I } \\
\text { Membership }\end{array}\end{array}$ & 22.7 .87 & 14.10 .87 & 19.10 .87 & - & 12.11 .87 & 13.11 .87 \\
Examination & 22.7 .87 & 4.11 .87 & 9.11 .87 & 9.11 .87 & 15.12 .87 & 16.12 .87 \\
\hline
\end{tabular}

FEES ON EACH OCCASION MRCPsych Part I: $£ 1110.00$; Membership Examination: $£ 130.00$

\section{Diploma in Family Therapy}

Applications are invited for this course aimed at training practitioners to work with families in a multi-cultural society. The one year course consists of $1 \frac{1}{2}$ days per week formal tuition which includes theory and reading seminars, live supervision of family work, videotape supervision and skills training. It will be supplemented by clinical experience, which can be gained either in the Bloomsbury Health District or in approved placements. Teaching staff will be drawn from the Marlborough Family
Service and various departments in University College, London.

Applicants must have a relevant professional qualification and must have completed some recognised introductory work in family therapy. Further information and application forms from: Dr Alan Cooklin, Course Director or Miss Ann Miller, Course Organiser, Marlborough Family Service, 38 Marlborough Place, London NW8 0PJ (telephone 01624 8605).

\section{Diploma in Medical Education}

The Centre for Medical Education at the University of Dundee is offering a Diploma in Medical Education for doctors and other health professionals. Ideas and theories of education are explained and applied to medical situ- ations and the diploma contains a management module. Further details: The Centre for Medical Education, 2 Roseangle, The University, Dundee DD1 4HN, Scotland. 